\title{
ANALISIS INTERAKSI SISWA DAN ORANG TUA YANG BEKERJA DI SMAN 1 MEMPAWAH
}

\author{
Heny Apriani \\ SMA Negeri 1 Mempawah \\ Email: heni_je@yahoo.co.id
}

\begin{abstract}
This study aims to know the role of interaction between students and their parents who work at SMAN 1 Mempawah. This research is conducted according to descriptive qualitative method. The technique used to collecting the data are direct observation, direct communication and documentary studies, while the instrumen are observasi, inteview and documentation. The analysis of this research presented according to descriptive qualitative by 10 participants that consisting of 2 people in each 5 families. The results showed that the interaction between students and their parents in social contact and communication are well established. The kids kiss their parents' hand before go to school, and using their phone to communicate to their parents.
\end{abstract}

Keywords: Social Interaction, Parent Work 
Dalam kehidupan bermasyarakat, manusia merupakan makhluk sosial yang selalu melakukan hubungan atau berinteraksi dengan orang lain, karena manusia tidak bisa hidup sendirian dan memerlukan orang lain di dalam kehidupannya. Secara kodrati manusia akan selalu hidup bersama dan tidak bisa hidup tanpa bantuan dari orang lain.

Menurut Philipus (2006:22) interkasi sosial merupakan, "hubungan-hubungan sosial yang dinamis yang berkaitan dengan hubungan antara individu dengan individu, antara individu dengan kelompok, antara kelompok dengan kelompok.

Menurut Abdulsyani (2002:153) dalam interaksi sosial, "individu bertemu dengan individu lainnya secara tatap muka atau secara langsung, sedangkan yang tidak langsung yaitu dengan menggunakan media perantara untuk berinterksi.

Keluarga merupakan lingkungan yang pertama-tama anak melakukan interaksi. Interaksi dan komunikasi orang tua terhadap anak serta bagaimana orang tua memperlakukan anak memberikan pengaruh terhadap sikap anak yang jika berkelanjutan akan berkembang menjadi karakter yang terbentuk pada diri anak. Dalam kehidupan sehari-hari anak dan orang tua tidak lepas dari hubungan satu dengan lainya, dan manusia sebagai mahkluk sosial berhubungan dengan orang lain. Interaksi sosial anak dan orang tua yang bekerja mempunyai caracara agar tetap bisa berinteraksi yaitu dengan adanya kontak, komunikasi.

Interaksi anak dan orang tua harus lebih sering terjadi pada waktu sore hari atau malam hari setelah orang tua pulang bekerja untuk makan malam bersama atau kumpul bersama anak. Ketika ibu pun bekerja di luar rumah, tugas seorang ibu dirumah tetap menyiapkan makan malam untuk makan bersama anak. Jadi tugas pokok ibu walaupun bekerja tetap berjalan walau tidak sepenuhnya. Orang tua yang bijaksana tentu bisa mengatur waktu untuk urusan pekerjaan dan urusan rumah tangganya.

Walaupun orang tuanya jauh terhadap anak, mereka masih bisa berinteraksi menggunkan alat komunikasi seperti handpone. Alat komunikasi handphone ini sangat membantu orang tua dan anak berkomunikasi secara tidak langsung, sehingga orang tua bisa memantau dan memberikan perhatian secara tidak langsung kepada anak. Pada saat orang tua masih bekerja di siang hari sedangkan anak sudah pulang dari sekolahnya, sehingga orang tua bisa mengetahui apakah anaknya sudah pulang kerumah atau belum, dan orang tua juga bisa memantau keberadaan anak dan aktifitasnya di dalam rumah ataupun luar rumah. Perhatian orang tua kepada anak melalui handphone sangat pentiung sifatnya.

SMAN 1 Mempawah merupakan sekolah menengah favorit di wilayah kabupaten mempawah secara kuantitas karena berdasarkan data yang ada di sekolah tersebut meningkat, prestasi belajarnya pun sangat bagus. Di SMAN 1 Mempawah mayoritas orang tua siswa mempunyai pekerjaan. Orang tua yang memiliki pekerjaan bukan berarti interaksi antar anak dan orang tua semakin jarang. Apalagi anak SMA yang menginjak remaja, perlu bimbingan dan komunikasi yang lancar, sehingga anak merasa di perhatikan oleh orang tua mereka, dan anak masih di awasi oleh orang tua.

Arus globalisasi disadari atau tidak telah membawa perubahan gaya hidup 
dalam keluarga. Tingginya perubahan gaya hidup yang semakin modern sering membuat orang tua lupa akan tanggung jawab terhadap keluarga. Orang tua dituntut untuk bekerja mencari nafkah dalam upaya memenuhi kebutuhan keluarga. Bukan hanya kaum laki-laki saja yang bekerja akan tetapi kaum perempuan juga bekerja. Kaum perempuan yang tugas pokoknya mengasuh anak, sekarang memiliki peran ganda, bahkan telah menjadi suatu prioritas, bekerja di luar rumah.

Orang tua merasa cukup jika sudah memenuhi kebutuhan materiil saja, dalam proses hubungan anak dan orang tua bukan hanya dalam bentuk kebutuhan materiil saja, akan tetapi hubungan yang hakiki yaitu membangun komunikasi dan interaksi yang utuh lahir dan batin, serta tidak luput dari perhatian orang tua terhadap buah hati mereka.

Seperti yang diharapkan di atas interaksi yang baik antara anak dan orang

\section{METODE}

Penelitian ini berbentuk studi kasus dengan metode deskriptif kualitatif, yang menelaah kepada suatu kasus dilakukan secara intensif, mendalam, mendetail, dan komprehensif. Menurut Nawawi (2007: 67), metode deskriptif adalalah "prosedur pemecahan masalah yang diselidiki dengan menggambarkan/melukiskan keadaan subyek/obyek penelitian (seseorang, lembaga, masyarakat dan lain-lain) pada saat sekarang berdasarkan fakta-fakta yang tampak, atau sebagaimana adanya. Penelitian studi kasus ini mendeskripsikan beberapa fakta-fakta yang dijumpai mengenai interaksi siswa dan orang tua yang bekerja di SMAN 1 Mempawah. Instrument dalam penelitian kualitatif ini adalah peneliti itu sendiri tua yang bekerja akan terjadi terjadi apabila mempunyai cara-caranya untuk terus berinteraksi dan berkomunikasi dengan anak yaitu dengan adanya kontak, kontak langsung bisa terjadi ketika orang tua mempunyai waktu luang pada malam hari mereka masih bisa berinteraksi dengan anaknya, masih bisa meluangkan waktu bersama anak. Orang tua akan tetap biasa melakukan kontak terhadap anak, seperti pada saat orang tua jauh dengan anak mereka masih bisa berinteraksi dan berkomunikasi dengan menggunakan alat komunikasi handpone. Dengan begitu anak akan terus mendapatkan perhatian dari orang tuanya.

Berdasarkan latar belakang yang telah dikemukakan diatas, terkait interaksi siswa dan orang tua yang bekerja mendorong peneliti untuk mengetahui "Analisis interaksi siswa dan orang tua yang bekerja di SMAN 1 Mempawah".

dan dibantu dengan wawancara serta observasi yang dilakukan saat penelitian. Karena peneliti secara langsung sebagai instrument maka peneliti harus memiliki kesiapan ketika melakukan penelitian, mulai dari awal proses penelitian hingga akhir proses penelitian. Lokasi penelitian ini dilakukan di SMAN 1 Mempawah di Jalan Raden Kusno. Teknik pengumpulan data yang digunakan dalam penelitian ini adalah observasi, wawancara, dan dokumentasi. Dalam observasi, cara mengumpulkan data yang dilakukan adalah melalui pengamatan secara langsung, yaitu dengan pergi ke lokasi guna melihat keadaan yang tampak pada objek penelitian. Selain itu, peneliti mengadakan wawancara langsung kepada 5 orang anak dan 5 orang tua yang bekerja yang menjadi informan yaitu RA, 
SH, GN, FS, RS dan orang tua yang bekerja ZR, KR, AG, NB, JM. Dokumentasi adalah teknik pengumpulan data dengan mencari dan mengumpulkan data yang ada hubungan dengan masalah yang akan diteliti melalui catatan yang berhubungan dengan masalah penelitian. Sumber data dalam penelitian ini adalah sumber data primer dan sumber data sekunder. Sumber data primer adalah sumber data yang diperoleh secara langsung melalui wawancara dengan informan. Sumber data sekunder merupakan data yang diperoleh secara tidak langsung dari sumbernya seperti data latar belakang siswa yaitu yang didapat dari arsip-srsip yang dimiliki sekolah sepeti pekerjaan orang tua.

Dalam setiap penelitian untuk menjawab permasalahan yang ada dalam penelitian diperlukan teknik dan alat pengumpulan data yang tepat yaitu teknik observasi, teknik wawancara dan teknik dokumentasi. Dalam penelitian ini, HASIL PENELITIAN DAN PEMBAHASAN

Hasil Penelitian

Dalam penelitian ini peneliti mengamati tentang bagaimana interaksi sosial antar siswa dan orang tua yang bekerja di SMAN 1 Mempawah. Adapun interaksi sosial antar santriwati berbagai pengujian keabsahan data menggunakan teknik Triangulasi. Menurut Sugiyono (2011:372) "triangulasi diartikan sebagai pengecekan data dari berbagai sumber dengan berbagai cara dan berbagai waktu". Sehubungan dengan teknik pengelolaan data maka peneliti merencanakan berdasarkan jenis data yang di peroleh selama dilapangan. Untuk jenis data yang diperoleh berdasarkan observasi dan wawancara dilakukan dengan mengacu kepada panduan observasi dan panduan wawancara yang akan dikembangkan. Hasil dari pemngamatan data seperti daftar observasi, dan wawancara diolah dengan mendeskripsikan secara kualitatif sebagaimana fakta yang ditemukan di lapangan. Sedangkan dokumen/arsip digunakan untuk mendukung dan melengkapi deskripsi sebelum diolah dengan penelitian triangulasi.

etnik dilihat dari 2 item penting yaitu, interaksi dalam bentuk kontak pada siswa dan orang tua yang bekerja di SMAN 1 Mempawah, dan interaksi dalam bentuk komunikasi pada siswa dan orang tua yang bekerja di SMAN 1 Mempawah.

Tabel 1

Identitas Informan

\begin{tabular}{cccccc}
\hline No & Nama Informan & Nama ayah & Nama Ibu & Pekerjaan Ayah & Pekerjaan Ibu \\
\hline 1 & RA & MP & ZR & PNS & PNS \\
\hline 2 & SH & SE & KR & SWASTA & PNS \\
\hline 3 & GN & SG & AG & TNI-AD & PNS \\
\hline 4 & FS & SH & NB & PNS & SWASTA \\
\hline 5 & RS & MY & JM & SWASTA & SWASTA \\
\hline
\end{tabular}




\section{Hasil Observasi \\ Kontak Sosial Siswa dan Orang Tua yang Bekerja di SMAN 1 Mempawah}

1) Kontak Primer

Data observasi dalam penelitian ini diperoleh dari hasil pengamatan yang dilakukan peneliti terhadap siswa dan orang tua yang bekerja. Berdasarkan hasil observasi sebanyak 4 kali kepada setiap informan, peneliti menemukan setiap informan melakukan kontak secara langsung dengan berjabat tangan, yang dilakukan oleh informan saat pergi ke sekolah. Pada observasi pertama tanggal 30 juli 2015 pukul 06.50 peneliti melihat RA mencium tangan ibunya ketika orang ibunya sedang berada didapur. Pada observasi kedua tanggal 31 juli 2015 pukul 06.45 peneliti melihat RA mencium tangan ibunya yang sedang menyapu di ruang tv. Pada observasi ketiga tanggal 1 agustus 2015 pukul 06.50 peneliti melihat RA mencium tangan orang tuanya ketika orang tuanya mau berangkat kerja. Pada observasi keempat tanggal 2 agustus 2015 pukul 06.49 peneliti melihat RA mencium tangan orang tuanya ketika ibunya ketika ibunya mau berangkat kerja.

Pada observasi pertama tanggal 5 agustus 2015 pukul 06.30 peneliti melihat SH mencium tangan dan pamitan ke pada ibunya sebelum berangkat ke sekolah ketika ibunya berada di dapur. Pada observasi kedua tanggal 6 agustus 2015 pukul 06.35 peneliti melihat SH mencium tangan dan pamitan ke pada ibunya ketika ibunya mau berangkat kerja. Pada observasi ketiga tanggal 7 agustus 2015 pukul 06.20 peneliti melihat SH mencium tangan dan pamitan ke pada ibunya ketika ibunya baru selesai mandi. Pada observasi keempat tanggal 8 agustus 2015 pukul 06.40 peneliti melihat $\mathrm{SH}$ mencium tangan dan pamitan ke pada ibunya ketika ibunya mau berangkat kerja.

Pada observasi pertama tanggal 12 agustus 2015 pukul 06.50 peneliti melihat GN mencium tangan dan pamitan ke pada orang tuanya sebelum berangkat ke sekolah ketika orang tuanya mau berangkat kerja. Pada observasi kedua tanggal 13 agustus 2015 pukul 06.47 peneliti melihat GN mencium tangan dan pamitan ke ibunya sebelum berangkat ke sekolah ketika ibunya sedang membereskan meja makan. Pada observasi ketiga tanggal 14 agustus 2015 pukul 06.50 peneliti melihat GN mencium tangan dan pamitan kepada ibunya sebelum berangkat ke sekolah ketika ibunya mau berangkat kerja. Pada observasi keempat tanggal 15 agustus 2015 pukul 06.50 peneliti melihat GN mencium tangan dan pamitan ke ibu sebelum berangkat ke sekolah ketika ibunya sedang bersiap-siap untk berangkat kerja.

Pada observasi pertama tanggal 18 agustus 2015 pukul 06.40 peneliti melihat FS mencium tangan dan cium pipi ibunya sebelum berangkat kesekolah ketika ibunya sedang menyuci pakaian. Pada observasi kedua tanggal 19 agustus 2015 pukul 06.48 peneliti melihat FS mencium tangan dan cium pipi ibunya sebelum berangkat kesekolah ketika ibunya sedang menyapu di ruang tamu. Pada observasi ketiga tanggal 20 agustus 2015 pukul 06.50 peneliti melihat FS mencium tangan dan cium pipi ibunya sebelum berangkat kesekolah ketika ibunya sedang membersikan dapur. Pada observasi keempat tanggal 21 agustus 2015 pukul 06.38 peneliti melihat FS mencium tangan dan cium pipi ibunya sebelum berangkat kesekolah ketika ibunya sedang mengepel rumah.

Pada observasi pertama tanggal 26 agustus 2015 pukul 06.50 peneliti melihat 
RS berpamitan dan mencium tangan orang tua nya sebelum berangkat sekolah ketika orang tuanya sedang membersihkan ruang dapur. Pada observasi kedua tanggal 27 agustus 2015 pukul 06.48 peneliti melihat RS berpamitan dan mencium tangan orang tua nya sebelum berangkat sekolah ketika orang tuanya sedang menyapu halaman rumah. Pada observasi pertama tanggal 28 agustus 2015 pukul 06.50 peneliti melihat RS berpamitan dan mencium tangan orang tuanya sebelum berangkat sekolah ketika orang tuanya sedang duduk di depan teras. Pada observasi pertama tanggal 29 agustus 2015 pukul 06.49 peneliti melihat RS berpamitan dan mencium tangan orang tuanya sebelum berangkat sekolah ketika orang tuanya sedang menyapu di ruang tamu.

Berdasarkan hasil observasi menunjukan bahwa setiap anak pada saat pergi kesekolah melakukan kontak langsung yaitu dengan mencium tangan orang tua dan berpamitan.

\section{2) Kontak Sekunder}

Selama observasi berlangsung sebanyak 4 kali kepada setiap informan berlangsung peneliti melihat semua informan dapat menjalankan perannya. Dalam beraktivitas sehari-hari diperlukan alat komunikasi yang digunakan informan untuk berkomunikasi maupun untuk mengakses informasi. Apa lagi orang tua yang bekerja, dan anak jauh dari jangkauan orang tua. Selama observasi peneliti menemukan bahwa semua informan memiliki alat komunikasi yaitu handphone yang digunakan anggota keluarga untuk berkomunikasi dan dalam mengakses informasi, pada observasi pertama tanggal 30 juli 2015 pukul 15.00-20.00 peneliti tidak menemukan RA berkomunikasi dengan orang tuanya menggunakan handphone karena RA dan orang tua RA sedang berada di rumah. Observasi ke dua pada tanggal 31 juli 2015 pukul 16.15 peneliti menemukan RA sedang menelpon bapaknya karena ada teman ayahnya yang datang kerumah, sedangkan bapaknya lagi tidak ada dirumah. Pada observasi ketiga tanggal 1 agustus 2015 pukul 14.30 RA di telepon oleh ibunya yang menanyakan keberadaan RA, dan menanyakan apakah RA akan pergi kerumah neneknya yang dibakau karena orang tua RA sudah berada dirumah neneknya. Observasi ke empat tanggal 2 agustus 2015 pukul 20.35 RA sms ke ibunya kalau RA akan pulang terlambat karena RA lagi di rumah temannya.

Pada observasi pertama pada tanggal 5 agustus 2015 pukul 17.20 peneliti menemukan SH lagi membalas sms dari ibunya, ibunya pulang terlambat karena masih melatih erobik. Pada observasi ke dua tanggal 6 agustus 2015 pukul 15.10 SH sms ke ibunya untuk pamitan dan memberi tahu kalau SH mau kerja kelompok di rumah teman, karena pada saat itu ibu SH lagi tidak ada dirumah. Observasi ke tiga pada tanggal 7 agustus 2015 pukul 16.25-20.40 peneliti tidak menemukan SH atau orang tua SH saling berkomunikasi melalui handphone di karenakan pada hari itu SH dan orang tua $\mathrm{SH}$ sedang berada dirumah dan tidak kemana-mana. Pada oservasi ke empat pada tanggal 8 agustus 2015 pukul 20.30 ibu SH membaca sms dari SH bahwa SH pulang agak telat sekitar pukul 21.30 SH pulang kerumah dikarenakan malam minggu.

Pada observasi pertama tanggal 12 agustus 2015 pukul peneliti menemukan $16.25 \mathrm{ibu}$ GN sedang membaca sms dari GN yang memberi tahukan kalau GN sedang dirumah temannya untuk mengerjakan tugas. Pada observasi ke 
dua tanggal 13 agustus 2015 pukul 15.4020.00 peneliti tidak menemukan $\mathrm{GH}$ dan orang tuanya menggunakan alat komunikasi handphone di kerenakan GH dan orang tua nya sedang ada dirumah. Observasi ke tiga pada tanggal 14 agustus 2015 pukul 15.45 peneliti menemukan GH mengangkat telepon dari ibunya, karena ibunya sedang tidak ada dirumah. Pada observasi ke empat tanggal 15 agustus 2015 pukul 15.30 ibu GH menelpon $\mathrm{GH}$ dan menanyakan keberadaan GH lagi dimana karena GH sedang tidak ada dirumah.

Pada observasi pertama tanggal 18 agustus 2015 pukul 19.35 peneliti menemukan FS sedang di telepon oleh bapaknya. Pada observasi kedua tanggal 19 agustus 2015 pukul 18.20-20.25 peneliti tidak menemukan komunikasi menggunakan handphone antara FS dan oranag tuanya karena FS dan ibunya lagi ada dirumah dan bapak FS pada hari itu tidak menelpon FS. Pada observasi ke tiga 20 agustus 2015 pukul 19.40 peneliti menemukan FS mengangkat telepon dari bapaknya. Pada observasi ke empat tanggal 21 agustus 2015 pukul 14.20 peneliti menemukan ibu FS sedang menelpon FS dan menanyakan FS lagi berada dimana dan menyuruh FS pulang kerumah.

Pada observasi pertama tanggal 26 agustus 2015 pukul 16.00 peneliti menemukan ibu RS sedang menelpon RS yang menanyakan keberadaan RS dimana. Pada observasi ke dua tanggal 27 agustus 2015 pukul 19.15 peneliti menemukan RS sedang sms ibunya untuk memberi tahukan bahwa RS mau kerumah temannya karena pada saat itu orang tua RS lagi tidak ada di rumah. Pada observasi ke tiga tanggal 28 agustus 2015 pukul 16.00-20.30 peneliti tidak menemukan RS berkomunikasi dengan orang tuanya melalui handphone karena
RS dan orang tuanya berada di rumah dan tidak kemana-mana. Pada observasi ke empat pada tanggal 29 agustus 2015 pukul 16.35 peneliti menemukan ibu RS menelpon RS yang sedang berada di luar rumah untuk pulang kerumah.

Berdasarkan hasil observasi menunjukan bahwa setiap anak dan orang tua menggunakan alat komunikasi handphone untuk berkomunikasi pada jarak jauh.

\section{Komunikasi siswa dan orang tua yang bekerja di SMAN 1 Mempawah}

1) Komunikasi Verbal

Berdasarkan hasil observasi sebanyak 4 kali kepada setiap informan, peneliti menemukan setiap informan melakukan komunikasi dengan menggunakan bahasa melayu dengan jelas dan dapat dimengerti terlihat pada obeservasi pertama tanggal 30 juli 2015 pukul 18.40 peneliti melihat RA dan orang tuanya makan malam bersama. Selesai makan malam bersama RA dan orang tuanya kumpul di ruang tv, mereka saat berbicara dan berinteraksi menggunakan bahsa melayu yang dapat dimengeri oleh RA dan orang tuanya. Pada obeservasi kedua tanggal 31 juli 2015 pukul 18.50 peneliti melihat RA dan orang tuanya makan malam bersama. Selesai makan malam bersama RA dan orang tuanya kumpul di ruang tamu, ketika RA berinteraksi mereka menggunakan bahasa melayu yang dapat dimengerti. Pada obeservasi ketiga tanggal 1 agustus 2015 pukul 18.45 peneliti melihat RA dan orang tuanya makan malam bersama. Selesai makan malam bersama RA dan orang tuanya kumpul di ruang tv, ketika pada saat RA berinteraksi mereka menggunakan bahasa melayu yang dapat dimengerti. Pada obeservasi keempat tanggal 2 agustus 2015 pukul 18.50 peneliti melihat 
RA dan orang tuanya makan malam bersama, setelah makan malam bersama RA dan ibunya santai di teras rumah, mereka berinteraksi menggunakan bahasa melayu yang dapat dimengerti.

Pada obeservasi pertama tanggal 5 agustus 2015 pukul 18.25 peneliti melihat SH dan orang tuanya makan malam bersama. Selesai makan malam bersama SH dan orang tuanya sedang kumpul bersama di ruang tamu dan saat ibu $\mathrm{SH}$ menasehati $\mathrm{SH}$ ia menggunakan bahasa melayu yang dapat dimengeti. Pada obeservasi kedua tanggal 6 agustus 2015 pukul 18.40 peneliti melihat $\mathrm{SH}$ dan orang tuanya makan malam bersama. Selesai makan malam bersama SH dan orang tuanya sedang kumpul bersama di ruang tv, mereka berinteraksi menggunakan bahasa melayu yang dapat dimengeti. Pada obeservasi ketiga tanggal 7 agustus 2015 pukul 18.30 peneliti melihat $\mathrm{SH}$ dan orang tuanya makan malam bersama. Selesai makan malam bersama $\mathrm{SH}$ dan orang tuanya sedang sanatai di teras rumah, pada saat mereka berinteraksi menggunakan bahasa melayu yang dapat dimengeti oleh kedua belah pihak. Pada obeservasi keempat tanggal 8 agustus 2015 pukul 18.20 peneliti melihat $\mathrm{SH}$ dan orang tuanya makan malam bersama. Selesai makan malam bersama SH mengerjakan PR di ruang tamu, saat ibu SH menanyakan sesuatu kepada $\mathrm{SH}$ ia menggunakan bahasa melayu dan $\mathrm{SH}$ menjawab dengan menggunakan bahasa melayu juga.

Pada obeservasi pertama tanggal 12 agustus 2015 pukul 18.30 peneliti melihat $\mathrm{GH}$ dan orang tuanya makan malam bersama. Selesai makan malam bersama GH dan orang tuanya sedang kumpul bersama di ruang tv, mereka berinteraksi dan berkomunikasi menggunakan bahasa melayu yang dapat dimengeti. Pada obeservasi kedua tanggal 13 agustus 2015 pukul 18.40 peneliti melihat $\mathrm{GH}$ dan orang tuanya makan malam bersama. Selesai makan malam bersama GH dan ibunya sedang duduk di ruang tamu, ibu $\mathrm{GH}$ berbicara mengenai sekolah $\mathrm{GH}$ dan mereka berinteraksi menggunakan bahasa melayu yang dapat dimengeti. Pada obeservasi ketiga tanggal 14 agustus 2015 pukul 18.35 peneliti melihat GH dan orang tuanya makan malam bersama. Selesai makan malam bersama $\mathrm{GH}$ dan orang tuanya sedang kumpul bersama di ruang tv, mereka bercanda dan berinteraksi menggunakan bahasa melayu yang dapat dimengeti. Pada obeservasi keempat tanggal 15 agustus 2015 pukul 18.30 peneliti melihat $\mathrm{GH}$ dan orang tuanya makan malam bersama. Selesai makan malam bersama GH dan orang tuanya sedang kumpul bersama di ruang tamu, ibu GH berbicara mengenai sekolah, menanyakan pelajaran GH dan mereka berinteraksi menggunakan bahasa melayu yang dapat dimengeti

Pada obeservasi pertama tanggal 18 agustus 2015 pukul 18.25 peneliti melihat FS dan ibunya makan malam bersama. Selesai makan malam bersama FS dan ibunya sedang santai di ruang tv, mereka berinteraksi dan berkomunikasi menggunakan bahasa melayu yang dapat dimengeti. Pada obeservasi pertama tanggal 19 agustus 2015 pukul 18.35 peneliti melihat FS dan ibunya makan malam bersama. Selesai makan malam bersama FS dan ibunya sedang sanatai di ruang tv, ibu FS menanyakan FS tentang sekolahnya, mereka berinteraksi dan berkomunikasi menggunakan bahasa melayu yang dapat dimengeti. Pada obeservasi ketiga tanggal 20 agustus 2015 pukul 18.30 peneliti melihat FS dan ibunya makan malam bersama. Selesai makan malam bersama FS dan ibunya sedang santai di ruang tv, sambil 
menonton tv, ibu FS dan FS mengobrol dan mereka berinteraksi menggunakan bahasa melayu yang dapat dimengeti. Pada obeservasi pertama tanggal 21 agustus 2015 pukul 18.20 peneliti melihat FS dan ibunya makan malam bersama. Selesai makan malam bersama FS dan ibunya sedang sanatai di ruang tamu, mereka asik mengobrol dan menggunakan bahasa melayu yang dapat dimengeti.

Pada obeservasi pertama tanggal 26 agustus 2015 pukul 18.20 peneliti melihat RS dan orang tuanya makan malam bersama. Selesai makan malam bersama RS dan ibunya sedang sanatai di ruang tamu, ibu FS menanyakan pelajaran di sekolah dan mereka berinteraksi dan berkomunikasi menggunakan bahasa melayu yang dapat dimengeti. Pada obeservasi kedua tanggal 27 agustus 2015 pukul 18.30 peneliti melihat RS dan orang tuanya makan malam bersama. Selesai makan malam bersama RS dan orang tuanya sedang santai di teras rumah, mereka berinteraksi dan berkomunikasi menggunakan bahasa melayu yang dapat dimengeti. Pada obeservasi ketiga tanggal 28 agustus 2015 pukul 18.35 peneliti melihat RS dan orang tuanya makan malam bersama. Selesai makan malam bersama RS dan orang tuanya sedang santai dan menonton tv, saat santai dan sambil menonton tv mereka juga berinteraksi dan berkomunikasi menggunakan bahasa melayu yang dapat dimengeti. Pada obeservasi keempat tanggal 27 agustus 2015 pukul 18.20 peneliti melihat RS dan orang tuanya makan malam bersama. Selesai makan malam bersama RS dan orang tuanya sedang santai di ruang tamu, RS dan orang tuanya asik mengobrol dan mereka berinteraksi dan berkomunikasi menggunakan bahasa melayu yang dapat dimengeti.
Berdasarkan hasil observasi menunjukan bahwa anak dan orang tua pada saat berkomunikasi menggunakan bahasa sehari-hari yaitu dengan menggunakan bahasa melayu yang dapat dimengerti ketika anak dan orang tua berbicara. Karena di lingkungan sekitar rumah, dan sekolah informan mayoritas menggunakan bahasa melayu.

\section{2) Komunikasi Non Verbal}

Berdasarkan hasil observasi sebanyak 4 kali kepada setiap informan, peneliti menemukan setiap informan melakukan gerak-gerik saat berbicara terlihat pada obeservasi pertama tanggal 30 juli 2015 pukul 19.30 peneliti melihat RA dan orang tua sedang kumpul bersama di ruang tv dan saat mereka berbicara menggunakan gerakkan tangan. Pada obeservasi kedua tanggal 31 juli 2015 pukul 19.15 peneliti melihat RA dan orang tua sedang mengobrol di ruang tamu, saat itu RA menggerakan kaki kekiri dan kekanan. Pada obeservasi ketiga tanggal 1 agustus 2015 pukul 19.20 peneliti melihat RA dan orang tua sedang kumpul bersama di ruang tv dan saat mereka berbicara menggunakan gerakkan tangan. Pada obeservasi keempat tanggal 2 agustus 2015 pukul 18.50 peneliti melihat RA dan ibunya sedang santai di teras rumah, saat mereka berbicara menggunakan gerakkan tangan dan RA mengerakkan kakinya

Observasi pertama pada tanggal 5 agustus 2015 pukul 18.45 peneliti melihat SH dan orang tua sedang kumpul bersama di ruang tamu dan saat ibu SH berbicara menggunakan gerakkan tangan ketika member nasehat untuk SH. Pada obeservasi kedua tanggal 6 agustus 2015 pukul 19.10 peneliti melihat $\mathrm{SH}$ dan orang tua sedang kumpul bersama di ruang tv dan saat mereka berbicara menggunakan gerakkan tangan. Pada 
obeservasi ketiga tanggal 7 agustus 2015 pukul 19.35 peneliti melihat $\mathrm{SH}$ dan orang tua sedang santai di teras rumah dan saat mereka berbicara menggunakan gerakkan tangan dan sesekali mengoyangkan kakinya. Pada obeservasi keempat tanggal 8 agustus 2015 pukul 18.45 peneliti melihat $\mathrm{SH}$ sedang mengerjakan PR, dan pada saat itu ibu SH menanyakan sesuatu kepada $\mathrm{SH}$, dan $\mathrm{SH}$ pun menggelengkan kepalanya sambil berkata "tidak tau bu".

Pada obeservasi pertama tanggal 12 agustus 2015 pukul 18.50 setelah makan malam peneliti melihat $\mathrm{GH}$ dan orang tua kumpul bersama di ruang tv dan saat mereka berbicara menggunakan gerakkan tangan. Pada obeservasi kedua tanggal 13 agustus 2015 pukul 19.10 peneliti melihat GH dan ibunya sedang duduk bersama di ruang tamu, ibu GH sedang berbicara mengenai sekolah GH dan saat mereka berbicara menggunakan gerakkan tangan. Pada obeservasi ketiga tanggal 14 agustus 2015 pukul 19.25 setelah makan malam peneliti melihat GH dan orang tua sedang kumpul bersama di ruang tv dan saat mereka berbicara menggunakan gerakkan tangan. Pada obeservasi keempat tanggal 15 agustus 2015 pukul 19.30 peneliti melihat GH dan orang tua sedang kumpul bersama di ruang tamu membicarakan sekolah GH dan sambil menggunakan gerakkan tangan.

Pada obeservasi pertama tanggal 18 agustus 2015 pukul 18.55 setelah makan malam peneliti melihat FS dan ibunya santai di ruang tv dan saat mereka berbicara FS mengerakan kepalanya sambil berkata "iya bu". Pada obeservasi kedua tanggal 19 agustus 2015 pukul 19.18 setelah makan malam peneliti melihat FS dan ibunya berbicara mengenai sekolah dan saat mereka berbicara menggunakan gerakkan tangan. Pada obeservasi ketiga tanggal 20 agustus
2015 pukul 19.25 setelah makan malam peneliti melihat FS dan orang tua kumpul bersama di ruang tv dan saat mereka berbicara menggunakan gerakkan tangan. Pada obeservasi keempat tanggal 21 agustus 2015 pukul 18.45 peneliti melihat FS dan ibunya mengobrol di ruang tamu dan berbicara menggunakan gerakkan tangan dan sambil mengetik handphone.

Pada obeservasi pertama tanggal 26 agustus 2015 pukul 18.45 peneliti melihat RS dan ibunya sedang santai di ruang tamu dan berbicara mengenai sekolah dan saat mereka berbicara RS mengerakkan jari tangannya. Pada obeservasi kedua tanggal 27 agustus 2015 pukul 19.20 setelah makan malam peneliti melihat RS dan orang tuanya sedang santai di teras rumah dan mereka berbicara menggunakan gerakkan tangan. Pada obeservasi ketiga tanggal 28 agustus 2015 pukul 19.10 peneliti melihat RS dan orang tuanya berada di ruang tv mereka berbicara dan menggunakan gerakkan tangan dan sesekali RS memegang hidungnya. Pada obeservasi keempat tanggal 29 agustus 2015 pukul 18.40 setelah makan malam peneliti melihat RS dan orang tuanya berbicara menggunakan gerakkan tangan dan sesekali RS mengerakan jari tangannya ketika berbicara di ruang tamu.

Berdasarkan hasil observasi menunjukan bahwa anak dan orang tua Saat berbicara menggunakan gerak-gerik seperti gerakan tangan ketika orang tua memberi nasehat kepada anak.

\section{Pembahasan}

Kontak sosial pada siswa dan orang tua yang bekerja di SMAN 1 Mempawah

Interaksi anak dan orang tua sangat penting, akan tetapi syarat terjadinya interaksi harus adanya kontak sosial dan komunikasi. Menurut 
Soekanto (2012 : 59) Kata kontak berasal dari "bahasa latin con atau cum (yang artinya bersama-sama) dan tango (yang artinya menyentuh)". Jadi, artinya secara harfiah adalah bersama-sama menyentuh. Secara fisik, kontak baru terjadi apabila terjadi hubungan badaniah. Suatu kontak dapat pula bersifat primer dan skunder.

Kontak sosial anak dan orang tua cukup baik karena pada saat anak pergi sekolah, anak berpamitan dan mencium tangan orang tua. Pada saat orang tua mempunyai kesibukan di luar tetapi orang tua masih bisa melakukan kontak skunder yaitu dengan menggunakan alat komunikasi handphone dengan anaknya. Dan ketika anak berada di luar rumah orang tua menanyakan keberadaan anak. Dengan perkembangan jaman terlihat semua informan mempunyai handphone. Jadi interaksi orang tua dan anak walaupun tidak bertemu masih bisa berkomunikasi dengan baik, dengan menggunakan handphone, akan tetapi tidak terjadinya interaksi melalui suatu pranata yaitu dengan menggunakan handphone apabila anak dan orang tua berada di dalam rumah dan tidak kemana-mana.

\section{Pembahasan Hasil Wawancara}

Berdasarkan hasil wawancara yang dilakukan peneliti terhadap siswa dan orang tua yang bekerja tentang kontak sosial, pada aspek kontak primer yaitu bertemu langsung bahwa anak lebih sering bertemu dengan ibunya di banding ayahnya. Banyak informan yang menyatakan bahwa anak lebih sering berkumpul dengan orang tua pada malam hari terutama pada saat makan malam setelah sholat maghrib, di perkuat dengan wawancara Robby, "habis selesai sholat magrib sering makan malam bersama keluarga kalau makan malam itu saya, bapak dan ibu selalu makan bersama- sama mungkin karena bapak dan ibu tidak terlalu sibuk" (wawancara 3 agustus 2015). Jika ada waktu luang setelah makan malam orang tua berkumpul bersama anak di waktu luang, dikarena kesibukan orang tua bekerja dari pagi sampai sore hari, dan anak sekolah. Pada saat malam hari intensitas waktu untuk keluarga sangat besar. Menurut informan Ibu Kartini (wawancara 11 agustus 2015) "Iya, sudah pasti kami sering ngumpul bersama, setelah makan malam, biasanya kami nyantai di teras rumah atau di ruang tv, ngomong-ngomong sama anak, tentang pelajaran dia di sekolah, memberi contoh yang baiknya terhadap anak. Habis kumpul bersama biasanya anak masuk kamar masing-masing buat belajar". Disini menegaskan bahwa orang tua menyempatkan waktu luang pada malam hari untuk berkumpul dengan anak.

Pada aspek berjabat tangan, berdasarkan observasi dan wawancara semua informan saat mau berangkat kesekolah, informan mencium tangan dan berpamitan kepada orang tua, hal itu terlihat pada salah satu informan yakni Galih yang menyatakan "Pamitan. Pamitan langsung, pada saat mau pergi sekolah pasti pamitan dan mencium tangan ibu dan bapak" (wawancara 16 agustus 2015).

Hal ini juga terlihat pada aspek kontak skunder yaitu dengan menggunakan suatu pranata seperti alat komunikasi handphone. Dari hasil wawancara dengan informan, alat komunikasi handphone sangat penting untuk berkomunikasi jarak jauh, apa lagi pada anak yang menginjak remaja pada saat ini, komunikasi orang tua harus terus berjalan walaupun orang tua sedang tidak ada dirumah. Menurut informan Ibu Agutina (wawancara 17 agustus 2015) "Iya, saya sering menggunakan hp untuk 
menelpon anak, kalau saya lagi ada urusan di luar rumah saya selalu menelpon anak. Biasa 5 atau 10 menit menelpon, karena dia kan sudah bujang sudah menginjak remaja, jadi harus di wanti-wanti. Bimbang juga ninggalin dia di rumah kalau saya lagi tidak di rumah". Bukan hanya orang tua saja yang selalu berkomunikasi akan tetapi anak juga harus menjga komunikasi dengan orang tua. Dapat disimpulakan berdasarkan hasil wawancara menunjukkan bahwa kontak sosial siswa dan orang tua yang bekerja di SMAN 1 Memapawah sudah baik.

\section{Komunikasi siswa dan orang tua yang bekerja di SMAN 1 Mempawah \\ Komunikasi adalah bagian} terpenting dalam interaksi. Menurut Bernard Berelson \& Gary A. Steiner (dalam Riswandi 2013: 1) Komunikasi adalah "suatu proses penyampaian informasi, gagasan, emosi, keahlian, dan lain-lain melalui penggunaan simbolsimbol seperti kata-kata, gambar, angkaangka dan lain-lain".

Berdasarkan hasil observasi yang dilakukan oleh peneliti sebanyak 4 kali pada setiap informan pada saat anak dan orang tua melakukan komunikasi verbal, anak dan orang tua berkomunikasi menggunakan bahasa sehari-hari yaitu bahasa melayu yang dapat di mengerti ketika anak dan orang tua berbicara. Karena di lingkungan sekitar rumah, dan lingkungan sekolah mayoritas menggunakan bahasa melayu.

Berdasarkan hasil observasi yang dilakukan oleh peneliti sebanyak 4 kali pada setiap informan observasi komunikasi non verbal saat berbicara anak dan orang tua menggunakan gerakgerik tubuh seperti gerakan tangan ketika orang tua memberi nasehat kepada anak, dan pada saat SH ditanya oleh ibu nya, iya hanya menggelengkan kepala sambil berkata "tidak tau bu". Dapat disimpulkan bahwa pada saat anak dan orang tua berkomunikasi menggunakan bahasa melayu, anak dan orang tua juga menggunakan gerak-gerik tubuh, seperti gerakan tangan saat berbicara.

\section{Pembahasan Hasil Wawancara}

Berdasarkan hasil observasi yang peneliti lakukan serta wawancara yang peneliti lakukan pada informan secara umum dapat dikatan bahwa pada aspek komunikasi verbal informan saat berbicara menggunakan bahas melayu dengan jelas dan dapat dimengerti, hal ini disampaikan pada Syarifah "Kalau elli bahasa melayu yang sering di pergunakan" (wawancara tanggal 10 agustus 2015). Hal tersebut juga sama dengan informan yang bernama Fika, ia mengatakan "bahasa melayu sering ngomong sama ibu, jarang ngikutin bahasa yang lainnya." (wawancara tanggal 24 agustus 2015). Karena pada lingkungan sekolah dan pada lingkungan tempat tinggal informan mayoritas menggunakan bahasa melayu.

Pada aspek komunikasi non verbal berdasarkan hasil wawancara adapun gerak-gerik yang dilakukan saat sedang berbicara dengan orang tua, seperti gerakan kepala pertanda menolak seperti pada wawancara informan yang bernama Syarifah, "Iya sering menggunakan gerak-gerik saat berbicara sama ibu. Seperti pada saat saya menggelengkan kepala kalau saya tidak suka dengan sesuatu" (wawancara pada tanggal 10 agustus 2015). Gerakan tubuh bisa dipahami seperti isyarat bahwa kita menyukai sesuatu atau tidak, melalui gerakan seperti Syarifah yang menggelengkan kepalanya pertanda bahwa Syarifah tidak suka dengan sesuatu. 
Adapun gerakkan yang dilakukan anak saat dimarahi orang tua nya, banyak informan mengatakan bahwa saat mereka dimarahi orang tuanya, mereka langsung masuk ke kamar diperkuat dengan wawancara informan Syarifah "Kalau lagi di marah sama ibu biasa elli diam, mekap dalam kamar, nangis. Tapi sebentar kalau lagi di marah sama mama, pandai-pandai cari perhatian ibu lagi, supaya marah nya hilang (wawancara pada tanggal 10 agustus 2015). Berbeda dengan orang tua, ketika orang tua merasa marah ke pada anak, orang tua akan memanggil anaknya langsung dan berbicara secara baik-baik tanpa adanya emosi atau kekerasan, hal ini terlihat pada saat wawancara Ibu Jamilah (wawancara pada tanggal 31 agustus 2015) "Saya

\section{SIMPULAN DAN SARAN Simpulan}

Berdasarkan hasil penelitian dan pembahasan mengenai analisis interaksi siswa dan orang tua yang bekerja di SMAN 1 Mempawah, maka dapat ditarik kesimpulan secara umum dari interaksi siswa dan orang tua yang bekerja tersebut dibagi menjadi dua bagian. Adapun bagian tersebut yaitu kontak pada siswa dan orang tua yang bekerja, dan komunikasi pada siswa dan orang tua yang bekerja. Hal ini dapat terlihat dari hasil observasi dan wawancara yang dilakukan oleh peneliti. Lebih khusus lagi dapat disimpulkan sebagai berikut : (1) Kontak antara siswa dan orang tua yang bekerja sudah cukup baik,karena pada kontak sosial primer terlihat ketika anak ingin pergi kesekolah mencium tangan orang tua dan memberi salam, adapun ketika selesai makan malam anak dan akan langsung manggil dan berbicara sama anak, kalau dia mengakui kesalahannya saya akan menasehatinya dengan kata-kata, sudah besar jugakan jadi tidak mungkin menggunakan kekerasan apa lagi sampai memukul anak. Kalau anak yang marah atau ngambek biasa mukanya masam, diam tidak negur mamanya. Nah disitu siapa tahan untuk lama diam, tidak menegur mama nya, yang lama diam ya pasti rugi". Dalam wawancara dengan informan tidak ada kode-kodean saat berbicara, ketika anak meminta sesuatu atau mengiginkan sesuatu anak langsung berbicara kepada orang tuanya. Dapat disimpulkan komunikasi yang dilakukan siswa dan orang tua sudah baik.

orang tua kumpul bersama. Adapun kontak sosial skunder, pada saat orang tua berada jauh dari anak, orang tua masih bisa berkomunikasi dengan anak menggunakan alat komunikasi yaitu handphone. (2) Komunikasi adalah bagian terpenting dari interaksi. Komunikasi anak dan orang tua menggunakan bahasa melayu dan katakata yang jelas dan dapat di mengerti oleh kedua belah pihak, dan menggunakan gerak-gerik tubuh ketika berbicara seperti gerakan tangan saat orang tua menasehati anak, atau kebiasaan anak yang suka mengerkan kaki saat sedang santai bersama orang tua.

\section{Saran}

Berdasarkan hasil penelitian yang diperoleh serta pembahasan tentang hasil tersebut, maka peneliti memberikan saran-saran sebagai berikut : (1) Pada saat orang tua libur bekerja sebaiknya waktu 
luang di pergunakan dengan baik, dengan pergi berrekreasi bersama keluarga agar dapat menjalin hubungan yang lebih harmonis dan lebih dekat lagi antara anak dan orang tua, dan pada saat makan bersama seharusnya bukan hanya makan malam saja, akan tetapi pada sarapan pagi bersama seharusnya dilakukan antara anak dan orang tua. (2) Luangkan waktu untuk berkomunikasi dengan anak, mendekatkan diri kepada anak, bukan

\section{DAFTAR RUJUKAN}

Abdulsyani (2002). Sosiologi Skematika, Teori, dan Terapan. Jakarta: Bumi Aksara. Philipus, Ng dan Aini Nurul. (2006).

Sosiologi dan Politik. Jakarta: PT RajaGraindo Persada.

Nawawi, Hadari. (2007). Metode

Penelitian Bidang Sosial.

Yogyakarta: Gajah Mada

University Press. hanya ibu terhadap anak akan tetapi ayah terhadap anak juga agar komunikasi terjalin dengan baik, dengan begitu tanggung jawab orang tua dengan anak masih berjalan dengan baik, dan anakpun tidak merasa diabaikan atau terpengaruh dengan pergaulan yang tidak baik, masih ada bimbingan dengan bijaksana dari orang tua. Dan anakpun hendaknya menyadari bahwa orang tua bekerja juga untuk masa depan mereka.

Riswandi (2013). Psikologi Komunikasi. Yogyakarta: Graha Ilmu

Soekanto, Soerjono. (2012). Sosiologi suatu Pengantar. Jakarta: PT RajaGrafindo Persada

Sugiyono. (2011). Metode Penelitian

Kuantitatif, Kualitatif dan

R\&D. Bandung: Alfabeta. 